\title{
Agroforestry, climate change mitigation and livelihood security in India
}

\author{
Jyotish Prakash Basu \\ From Third International Congress on Planted Forests \\ Bordeaux, France; Dublin, Ireland; and Porto and Estoril, Portugal. 16-21 May 2013
}

\begin{abstract}
Background: The Indian Council of Agricultural Research has set a target for increasing forest cover from the present level of $23 \%$ of land area to $33 \%$ and agroforestry contributes to this target.

Methods: The effect of agroforestry on carbon sequestration and livelihood security of people in India was reviewed. Also, a survey was conducted in two regions of West Bengal, one drought-prone and the other in a mountainous district, to assess the contribution of agroforestry to human well-being and livelihood security.

Results: The average carbon sequestration potential of agroforestry systems is estimated to be 25 tha $^{-1}$ over 96 million ha but there is substantial regional variability. The survey showed that village communities are dependent on agroforestry systems for income, employment opportunities and livelihood security. An account is also given of Government forestry and tree-planting programmes that encourage the practice of silvipasture, agrisilviculture, and agrihorticulture in rain-fed and irrigated areas.
\end{abstract}

Conclusions: Agroforestry systems offer opportunities for the improvement of the livelihood of poor people through provision of economic and environmental security.

\section{Introduction}

Agroforestry in India contributes to the target set by the Indian Council of Agricultural Research for increasing forest cover from the present level of $23 \%$ of land area to $33 \%$. The Report of the Task Force of Greening India for Livelihood Security and Sustainable Development (Planning Commission 2001) has suggested that 10 million ha of irrigated land and 18 million ha of rain-fed land should be managed under agroforestry systems. The International Panel on Climate Change (IPCC) Third Assessment Report on Climate Change (McCarthy et al. 2001) has recognised the potential of agroforestry for addressing multiple problems and delivering a range of economic, environmental and socioeconomic benefits. Estimates of the carbon sequestration potential of agroforestry systems range from 0.7-1.6 Gt (Trexler and Haugen, 1994) to 6.3 Gt (Brown et al., 1996). Secondary environmental benefits include food availability, security of land tenure, increased

Correspondence: bjyotish@yahoo.com

West Bengal State University, Barasat, Kolkata 126, India farm income, restoration and maintenance of above- and below-ground carbon storage capacity, restoration and maintenance of biodiversity, and maintenance of watershed hydrology and soil conservation. Agro ecosystems can be designed to assist adaptation of communities and households to local and global change (Van Ardenne et al. 2003).

In tropical countries like India, planted crops such as poplars (Populus spp.) and eucalypts (Eucalyptus spp.) represent a well-managed and profitable activity. Rapidly-growing poplars are now a major component of woodlots and shelterbelts on many farm properties in South Asia. Torquebiau (1992) has suggested that home gardens supply $44 \%$ of global calorie intake and $32 \%$ of global protein consumption. Food-producing trees grown in agroforestry systems can increase the nutritional and economic security of poor people living in tropical countries (World Bank, 2006). For example, the fruit of many wild edible species have carbohydrate contents on a dry weight ${ }^{1}$ basis ranging from 32 to $88 \%$ (Sundriyal and Sundriyal, 2001).

\section{SpringerOpen ${ }^{\circ}$}

(c) 2014 Basu; licensee Springer. This is an Open Access article distributed under the terms of the Creative Commons Attribution License (http://creativecommons.org/licenses/by/2.0), which permits unrestricted use, distribution, and reproduction in any medium, provided the original work is properly cited. 
Community plantations yielding non-timber products in tribal areas of Jharkhand, India, have potential for conservation of useful species as well as for making a contribution to the well-being of local people (Quli, 2001). Such initiatives have enhanced likelihood of success as these tribal communities are dependent on wild resources for their livelihood. In Jharkhand, the tree component of agroecosystems is particularly valued for specific roles including that of host species to insects yielding marketable products such as silk (Singh et al.1994), lac products (Jaiswal et al., 2002), and honey (Dwivedi, 2001).

The forest cover of India is only $67.83 \mathrm{M}$ ha $(20.68 \%$ of the geographical area) and other tree cover is estimated as 9.99 $\mathrm{M}$ ha (3.04\% of the geographic area), thus the total forest and other tree cover is computed as 77.82 $\mathrm{M}$ ha, which is 23.68 per cent of its geographical area (FSI, 2003). In addition to this, about $25.72 \mathrm{M}$ ha area is under various types of tree plantations such as agroforestry, social forestry and farm forestry.

In India, a social forestry programme started in 1976. Under this programme, trees were planted in and around agricultural fields, railway lines, roadsides, river and canal banks, village common land and government waste land. The goal of social forestry is plantations by the people who can meet the growing demand for timber, fuelwood, fodder and other uses. With the introduction of a social forestry scheme, emphasis was given on the involvement of community participation in order to initiative more drive towards afforestation and rehabilitation of degraded forests.

Under farm forestry, individual farmers are encouraged to plant trees on their own farmland to meet their domestic needs of the family. In most of the cases the farmers are interested planting trees to provide the shade for the agricultural crops, wind shelters and soil conservation.

In the community, forestry plantations of trees are made on government land and the government has responsibility of providing seedlings, fertiliser but the community has to take responsibility for protecting the trees. The government of India has adopted Joint Forest Management (JFM) as a principal approach for community-based forestry. This programme now covers $27 \%$ of the national forest area across 27 states, and encompasses 100,000 village committees. About 300 million poor rural people in India depend on forests for at least part of their subsistence and cash livelihoods, which they earn from fuelwood, fodder, sal leaves, and a range of non-timber forest products, such as fruits, flowers, and medicinal plants.

A tree-planting programme in India was launched in the late 1970s to create more awareness about the benefits of tree culture. It was initially believed that farmers would plant only a few trees on homesteads or on uncultivated lands, intending them to be a source of fuelwood and fodder for personal use. In fact the number of tree plantations other than forests reached unexpectedly high rates (FSI,
2000). Eucalypts (hybrids of Eucalyptus tereticornis) were highly favoured by farmers. The proportion of eucalypts among tree seedlings distributed by the Forest Department was 94\% in Uttar Pradesh, 96\% in Haryana, 84\% in Gujarat, and $90 \%$ in the Punjab (National Council of Applied Economic Research 1987; Saxena, 1992). The State government of Uttar Pradesh had fixed an initial target of about 8 million seedlings to be distributed to the farmers in the State over the period 1979-1984. Due to unexpected demand for seedlings from farmers, about 350 million seedlings were distributed. Little information exists about the effect of the tree-planting programme on climate change.

Agroforestry systems in India include the use of trees grown on farms, community forestry and a variety of local forest management and ethnoforestry practices (Pandey, 1998). The Indian Council of Agricultural Research has classified systems used in different agro-climatic zones as silvipasture, agrisilviculture or agrihorticulture based on irrigated or rain-fed conditions. The practice of growing scattered trees on farmland is quite old. These trees are used for shade, fodder, fuelwood, food and medicinal purposes. Eucalypts and poplars are also grown in fields or on farm boundaries in the Punjab and Haryana. Traditional agroforestry systems include such practice of growing trees on farmlands used for fodder, fuelwood and vegetables etc. along with shifting cultivation in the Northeast India and Taungya cultivation. The Taungya ${ }^{2}$ cultivation system is used in Kerala, West Bengal, and Uttar Pradesh and to a limited extent in Tamil Nadu, Andhra Pradesh, Orissa, Karnataka, as well as in the Northeast hill regions. In addition, home gardens, tea plantation, wood lots and alder (Alnus spp.) -based agriculture are other kinds of agroforestry systems prevailing in India.

The first objective of the current study was examination of the carbon sequestration potential of agroforestry in different regions of India. Secondly, an attempt was made to show how agroforestry contributes to the well-being of people and their resilience to the impact of climate change. Lastly, some appraisal is made of programmes involving afforestation, reforestation, community forestry, social forestry and farm forestry introduced by the Government of India.

\section{Carbon sequestration potential of agroforestry Global context}

Agroforestry has a particular potential role in the mitigation of atmospheric accumulation of greenhouse gases (IPCC 2000). Of all land-use types considered in the IPCC Land-Use, Land-Use Change and Forestry Report, agroforestry was considered to have the highest potential for carbon sequestration in non-Annex I countries (Figure 1). Agroforestry systems offer opportunities for the creation of synergies between adaptation and mitigation, and have 
a technical mitigation potential of 1.1-2.2 PgC in terrestrial ecosystems over the next 50 years (Solomon et al. 2007). Additionally, 630 million ha of unproductive croplands and grasslands could be converted to agroforestry representing a carbon sequestration potential of 391,000 $\mathrm{MgC}$

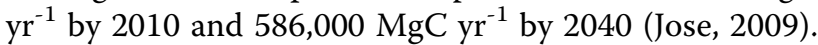
The amount of carbon in the above-ground and belowground biomass of an agroforestry system is generally much higher than in an equivalent land-use system without trees (Murthy et al. 2013).

In Southeast Asia, agrisilvicultural systems have the capacity for storing $12-228 \mathrm{MgC} \mathrm{ha}^{-1}$ in humid tropical lands and 68-81 $\mathrm{MgC} \mathrm{ha}^{-1}$ in dry lowlands (Murthy et al., 2013). The highest potential for carbon storage (90-198 $\mathrm{MgC} \mathrm{ha}{ }^{-1}$ ) is associated with North American silvipastoral systems. The potential for sequestering carbon in aboveground components of agroforestry systems is estimated

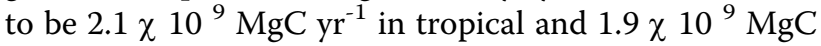
$\mathrm{yr}^{-1}$ in temperate biomes (Oelbermann et al., 2004). Agroforestry systems have indirect effects on carbon sequestration because they reduce harvesting pressure on natural forests which are the largest sinks for terrestrial carbon. They also conserve soil characteristics, thereby enhancing carbon storage in both trees and soil. Study of the effects of agroforestry practice on the soil carbon pool has indicated a rate of increase of 2-3 MgC.ha ${ }^{-1} \mathrm{yr}^{-1}$ (Garg, 1998). The carbon sequestration potential of tropical agroforestry systems is estimated to be $12-228 \mathrm{Mg} \mathrm{ha}^{-1}$ with a median value of $95 \mathrm{Mg} \mathrm{ha}^{-1}$ (Singh \& Pandey (2011). Other estimates based on the global area suitable for agroforestry (585-1215 × 106 ha) suggest that 1.1-2.2 PgC could be stored in terrestrial ecosystems during the next 50 years (Albrecht and Kandji, 2003). Other estimates of the

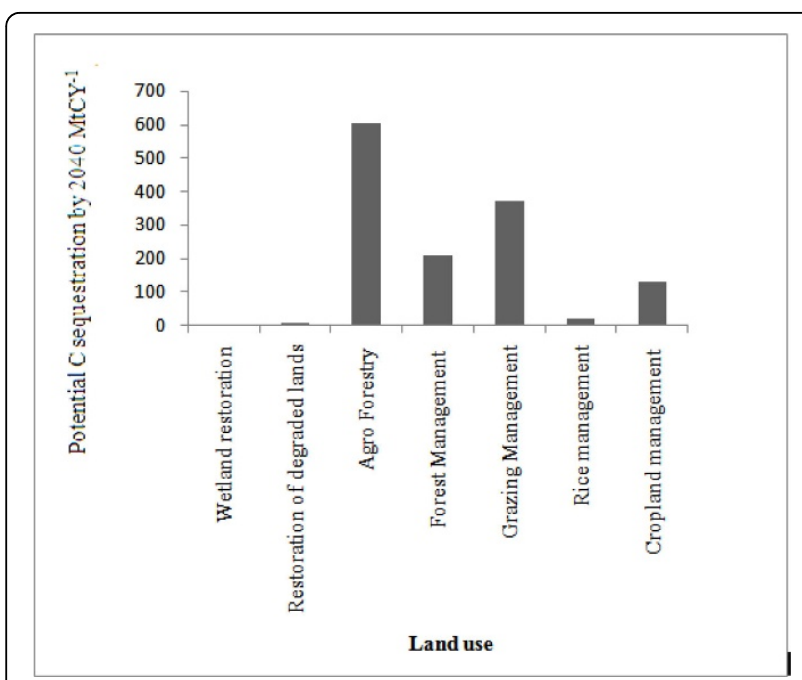

Figure 1 Carbon sequestration potential of different land-use and management options in non-Annex I countries (Source: Author's calculation) amount of carbon stored in agroforestry systems throughout the world range from 0.29 to $15.21 \mathrm{Mg} \mathrm{ha}^{-1} \cdot \mathrm{yr}^{-1}$ aboveground, and from 30 to $300 \mathrm{Mg} \cdot \mathrm{ha}^{-1} \cdot \mathrm{yr}^{-1}$ to $1 \mathrm{~m}$ depth in soil Ramchandran et al., 2010).

\section{Carbon sequestration potential in India}

The total carbon storage capacity of an agroforestry system depends on the growth and nature of the tree species, and varies from region to region (Newaj \& Dhyani, 2008). The average carbon storage potential in Indian agroforestry has been estimated to be $25 \mathrm{tC}$.ha ${ }^{-1}$ over 96 million ha (Sathaye and Ravindranath, 1998). Substantial regional variability is associated with biomass production (Table 1). Estimates of the rate of carbon sequestration under different agroforestry systems in India are presented in Table 2.

Estimates of net annual carbon sequestration in agroforestry crops (Table 3 ) indicate that components with the highest rates in India are poplar, eucalypt, and bamboo (species in the Bambusae tribe). Tropical home gardens have a particularly high carbon sequestration potential (16-36 Mgt ha $\left.^{-1} \mathrm{yr}^{-1}\right)$.

Koul et. al. (2011) estimated that soil organic carbon (SOC) was highest (17.69 t / ha) in natural forest of Shorea robusta Roth., followed by pure plantations of Terminalia arjuna (Roxb.) Wight \& Arn. (13.29 t / ha), agri-horticulture agroforestry systems $(12.14 \mathrm{t} / \mathrm{ha})$, pure plantations of Dalbergia sissoo Roxb. (10.66 t / ha) and tea (Camellia spp.) gardens (10.45 t / ha). The lowest amount of SOC stock was present in fallow land $(10.05 \mathrm{t} / \mathrm{ha})^{3}$.

\section{Contribution of agroforestry to human well-being and livelihood security}

India is noted for the existence of valuable local knowledge about tree planting. Small-holdings of less than 2 ha growing a combination of Acacia species and Oryza species (rice) in a traditional agroforestry system have been shown to have a benefit/cost ratio of 1.47 and an internal rate of return of $33 \%$ at an annual discount rate of $12 \%$ over a ten- year period (Singh and Pandey, 2011).

In the Northeast Indian state of Meghalaya, an agrihorticultural system based on Psidium spp. (guava) gave a 2.96fold higher net return than a comparable system without trees (Bhattacharya and Mishra 2003). Using Assam lemon as a horticulture-product based system was found to increase the net return 1.98 -fold. The net monetary benefit from the guava-based system was Rs. 20,610 ha ${ }^{-1}$ and that from Assam lemons was Rs. 3,787.60 ha ${ }^{-1}$. Similar systems are enhancing the livelihood of local people who were previously dependent on rain-fed agriculture. Estimates of net present value for different agroforestry systems in Haryana modelled on a six-year rotation varied between Rs. 26626 and Rs. 72705.ha ${ }^{-1} \cdot \mathrm{yr}^{-1}$ (Kumar, Gupta and Gulati, 2004). The benefit/cost ratio was 2.35 to 3.73 and the internal rate of return 94 to $389 \%$. These 
Table 1 Regional estimates of total carbon storage under different agroforestry systems in India.

\begin{tabular}{|c|c|c|c|c|}
\hline Region & Agroforestry system & Components & $\begin{array}{c}\text { Total carbon storage } \\
\left(\mathrm{tC} \cdot \mathrm{ha}^{-1}\right)\end{array}$ & Reference \\
\hline \multirow[t]{6}{*}{ Semi-arid } & Silvipasture aged $5 \mathrm{yr}$ & Acacia nilotica + natural pasture & $9.5-17.0$ & Rai et al. (2001) \\
\hline & & A. nilotica + established pasture & 19.7 & \\
\hline & & Dalbergia sissoo + natural pasture & 12.4 & \\
\hline & & D. sissoo + established pasture & 17.2 & \\
\hline & & Hardwickia binata + natural pasture & 16.2 & \\
\hline & & H. binata + established pasture & 17.0 & \\
\hline \multirow[t]{2}{*}{ North- western India } & $\begin{array}{l}\text { Silvipasture } \\
\text { aged } 6 \mathrm{yr}\end{array}$ & Acacia/Dalbergia/Prosopis + Desmostacya & $6.8-18.5$ & Kumar et al. (2002) \\
\hline & & Acacia/Dalbergia/Prosopis + Sporobolus & $1.5-12.3$ & \\
\hline Central India & Block plantation aged $6 \mathrm{yr}$ & Emelina arborea & $24.1-31.1$ & Swamy et al. (2003) \\
\hline \multirow[t]{3}{*}{ Arid (Rajasthan) } & $\begin{array}{l}\text { Agrisilviculture } \\
\text { aged } 8 \mathrm{yr}\end{array}$ & Emblica officinalis + Vigna radiata & $12.7-13.0$ & Singh (2003) \\
\hline & & Hardwickia binata + Vigna radiata & $8.6-8.8$ & \\
\hline & & Colophospermum mopane + Vigna radiata & $4.7-5.3$ & \\
\hline Semi-arid & Agrisilviculture aged $11 \mathrm{yr}$ & Dalbergia sissoo + crop & 26.0 & NRCAF (2007) \\
\hline \multirow[t]{3}{*}{ North-western Himalayas } & Silvipasture & & 2.17 & AICRPAF (2006) \\
\hline & Agrihortipasture & & 1.15 & \\
\hline & Hortipasture & & 1.08 & \\
\hline
\end{tabular}

agrihoticultural agroforestry systems, such as farming systems which combine domesticated fruit trees and forest trees have potential for lifting the socioeconomic status of farmers and for contributing to the overall development of the region.

Dhyani et al. (2003) focussed on the role of agroforestry products and environmental services in meeting subsistence needs and providing a basis for improved and sustainable wellbeing of society. They concluded that the

Table 2 Estimates of carbon sequestration potential under agroforestry in different agro-climatic regions in India.

\begin{tabular}{ll}
\hline \multicolumn{1}{c}{ Region } & \multicolumn{1}{c}{$\begin{array}{c}\text { Average carbon sequestration } \\
\text { rate }\end{array}$} \\
\hline Degraded forest land & $1.1 \mathrm{t} \mathrm{ha}^{-1} \mathrm{yr}^{-1}$ \\
Central Himalayas & $3.9 \mathrm{t} \mathrm{ha}^{-1} \mathrm{yr}^{-1}$ \\
Indo-Gangetic plains & $8.5-15.2 \mathrm{tha}^{-1} \mathrm{yr}^{-1}$ \\
Strip plantation aged 5.3 $\mathrm{yr}$ in & $15.5 \mathrm{t} \mathrm{ha}^{-1}$ during the first \\
Haryana & rotation \\
Agricultural soils of Indo-Gangetic & $12.4-22.6 \mathrm{t} \mathrm{ha}^{-1} \mathrm{yr}^{-1}$ \\
plains & \\
\hline
\end{tabular}

Source: Maikhuri et al. (2000). impact on livelihood is one of the major contributions made by agroforestry to the economy. This can be seen in terms of income, and in the generation of employment opportunities. There is potential for further employment under-improved agroforestry systems, amounting to 943 million person-days annually from 25.4 million ha (Table 4). Maximum employment opportunity is seen to be in tree-borne oil seeds, followed by silvipasture. Dhyani and Sharda \& Sharma (2005) have estimated that the potential of agroforestry for rural development and employment generation amounts to 5.763 million person-days $\mathrm{yr}^{-1}$ in the Himalayas alone.

The overall ratio of rate of return to investment in different agroforestry systems is estimated to be $117 \% \mathrm{yr}^{-1}$

Table 3 Estimates of net annual carbon sequestration by agroforestry components.

\begin{tabular}{ll}
\hline Agroforestry component & Carbon sequestration $\left(\mathbf{M g ~ h a}^{\mathbf{- 1}} \cdot \mathbf{y r} \mathbf{- 1}^{-1}\right)$ \\
\hline Populus spp. & 8 \\
Eucalyptus spp. & 6 \\
Bamboo spp. & $6.51-8.95$ \\
Tropical home gardens & $16-36$ \\
\hline
\end{tabular}

Source: Singh and Pandey (2011) 
Table 4 Employment generation potential of agroforestry in India.

\begin{tabular}{lccc}
\hline \multicolumn{1}{c}{ Agroforestry system } & Area (million ha) & Additional employment (person-days $\mathbf{h a}^{-\mathbf{1}} \mathbf{\mathbf { y r } ^ { - 1 } \text { ) }}$ & $\begin{array}{c}\text { Total annual employment } \\
\text { (million person-days) }\end{array}$ \\
\hline Silviculture & 1.8 & 30 & 53.3 \\
\hline Agrisilviculture (irrigated) & 2.3 & 40 & 91.3 \\
\hline Agrisilviculture (rainfed) & 1.3 & 30 & 38.0 \\
\hline Agrihorticulture(irrigated) & 1.5 & 50 & 76.1 \\
\hline Agrihorticulture(rainfed) & 0.5 & 40 & 20.3 \\
\hline Silvipasture & 5.6 & 30 & 167.4 \\
\hline Tree-borne oil seeds & 12.4 & 40 & 497.1 \\
\hline Total & 25.4 & - & 943.4 \\
\hline Source: NRCAF (2007) & & &
\end{tabular}

(Table 5). This ratio is highest under rain-fed agrisilviculture and irrigated agrisilviculture, followed by agrihorticulture and silviculture.

\section{West Bengal study}

The study was conducted in two different ecological regions of West Bengal namely, drought-prone and mountain regions in West Bengal. Data were collected by conducting field surveys in the drought-prone district of Bankura, West Bengal (Figure 2). This study was conducted in two villages, Jhunsura and Baskula, which are located in Sonamukhi forest area in the district of Bankura, one of the drought-prone districts of West Bengal (Figure 3). The study selected $30 \%$ households randomly from each village. In the village of Jhunsura there were 60 households and in the village of Baskula 60 households were selected on the basis of random sampling in 2011. A total of 120 structured household interviews were conducted. A similar study was conducted in another two villages namely; Khoirajhora forest basti which is situated on the foothills of Darjeeling and another is Rongtong (2) which is about 428 metres elevation in the mountain regions of Darjelling district (Figure 4) in 2011. In this area, the total sample size was 71 representing $30 \%$ households in both villages.

Thus, total number of sample households for four villages taken together was 191. Different socio-economic characteristics of the households were studied in terms of family size, age, sex, education, literacy rates and landholdings in the four villages. Secondary data were also taken from Forest Survey of India (FSI) and National Research Centre for Agro-forestry (NRCAF).

Socio-economic conditions of the households in both districts are poor and weak (Table 6). Non-timber forest products (NTFPs) were found to make an important contribution to livelihood security in the study area. The most common activities are collection and sale of fuel wood, leaves of Diospyros melanoxylon (kendu) and Shorea robusta (sal) for fodder, Gethi kanda (Dioscorea bulbifera), Bendo sag (Chenopodium album) (leafy vegetable) and bamboo. Similar results were obtained by Shit \& Pati (2012), who studied the Paschim Medinipur district of West Bengal. More than $80 \%$ of the villagers in the study areas were found to be directly dependent on NTFPs. Others use them indirectly, buying them when required. In both of the study areas fuel-wood collection was most important for livelihood (Figure 5). In the drought-prone area the next most important NTFP was sal leaf, whereas in the mountain region it was bamboo.

\section{Government programmes involving tree planting}

The Greening India mission under the National Climate Change Action Plan targets 1.5 Mha of degraded

Table 5 Rates of return from investment in agroforestry systems.

\begin{tabular}{lccc}
\hline Agroforestry system & $\begin{array}{c}\text { Investment } \\
\text { (Rs crore) }\end{array}$ & $\begin{array}{c}\text { Returns } \\
\text { (Rs crore) }\end{array}$ & $\begin{array}{c}\text { Ratio of rate of return to investment } \\
\left(\% \mathbf{~ y r}^{-1}\right)\end{array}$ \\
\hline Silviculture & 1548.16 & 1957.35 & 126 \\
Agrisilviculture (irrigated) & 2561.55 & 3843.67 & 150 \\
Agrisilviculture (rain-fed) & 1536.19 & 2418.16 & 157 \\
Agrihorticulture (irrigated) & 3607.97 & 4671.84 & 129 \\
Agrihorticulture (rain-fed) & 509.52 & 667.01 & 131 \\
Silvipasture & 4425.97 & 3929.13 & 89 \\
Tree-borne oil seeds & 1178.44 & 447.69 & 38 \\
\hline Overall & & & 117 \\
\hline
\end{tabular}

Source: NRCAF (2007) 


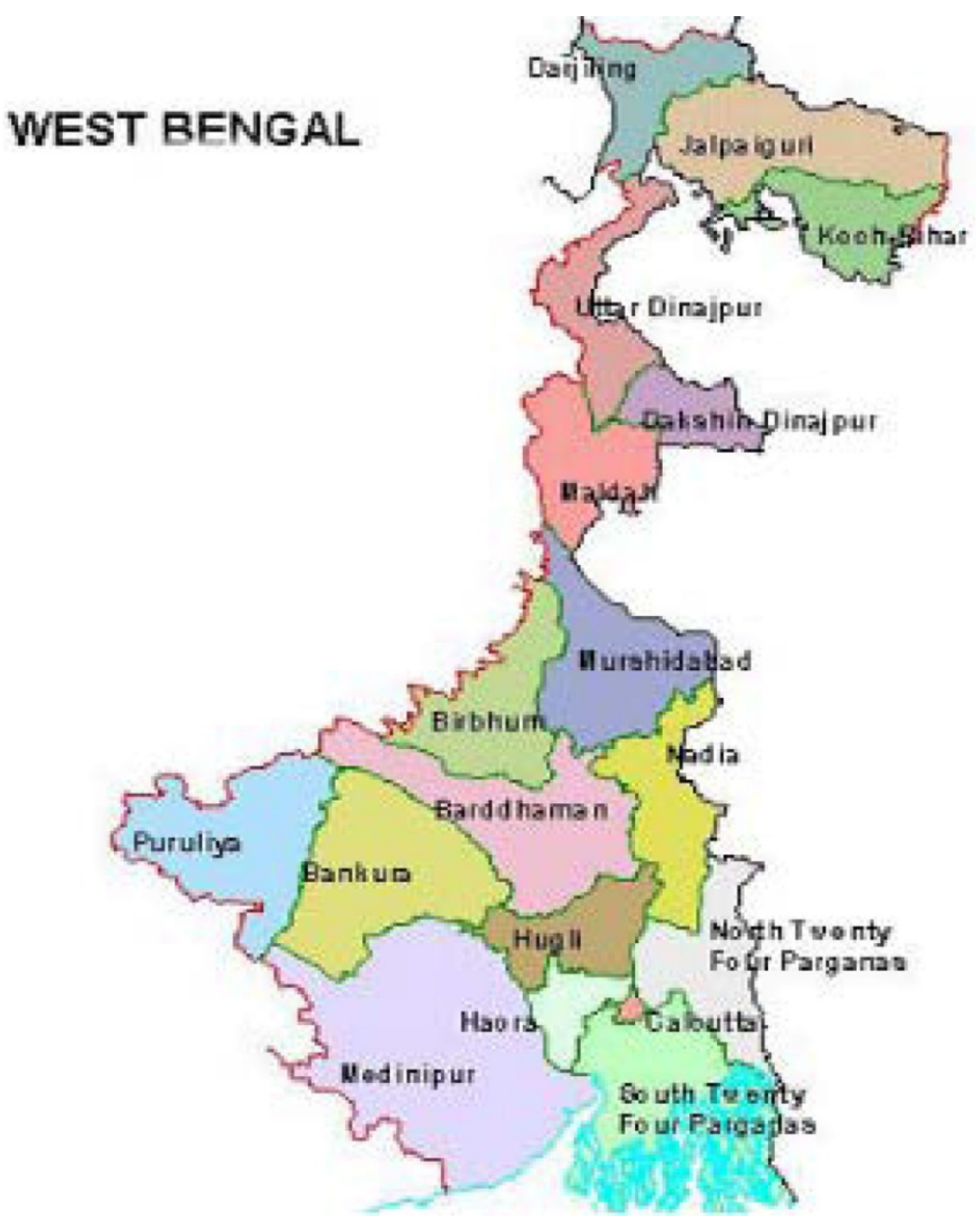

Figure 2 Map showing the location of West Bengal, India.

agricultural and fallow lands to be brought under agroforestry; about 0.8 Mha under improved agroforestry practices on existing lands and 0.7 Mha of additional lands under agroforestry (Puri \&Nair 2004). Much of the opportunity to store carbon through afforestation in India will occur through agroforestry on agricultural lands due to the fact that majority of arable land in India is being cultivated (Ravindranath 2007). The total potential for agroforestry has been estimated at 25.36 Mha with almost half of it under tree borne oilseeds, silvipasture and others by 2025 (NRCAF, 2007).

The National Forest Policy defined by the Government of India in 1988 aims to increase forest and tree cover throughout the country, thereby enhancing forest ecosystem services to local communities. Such services include, but are not restricted to, provision of timber, NTFPs and carbon sequestration. Afforestation and reforestation are currently carried out under various programmes, namely the Farm Forestry Programme launched in the late 1970s; a Social Forestry Programme initiated in the early 1980s; a Joint Forest Management Programme started in 1990; afforestation carried out under National Afforestation and Eco-development Board programmes since 1992; and private farmer- and industry-initiated plantation forestry schemes.

The Farm Forestry Programme was launched to create awareness about the benefits of tree planting. Under this intitiative, more trees were planted in commercialised and agrarian regions. Greatest enthusiasm was witnessed in the northern states of Punjab, Haryana, and western Uttar Pradesh, known collectively as the "green revolution belt". Here good alluvial soils are cultivated under assured irrigation and most trees are planted on boundaries around annual crops. Woodlot planting has been attempted mainly 


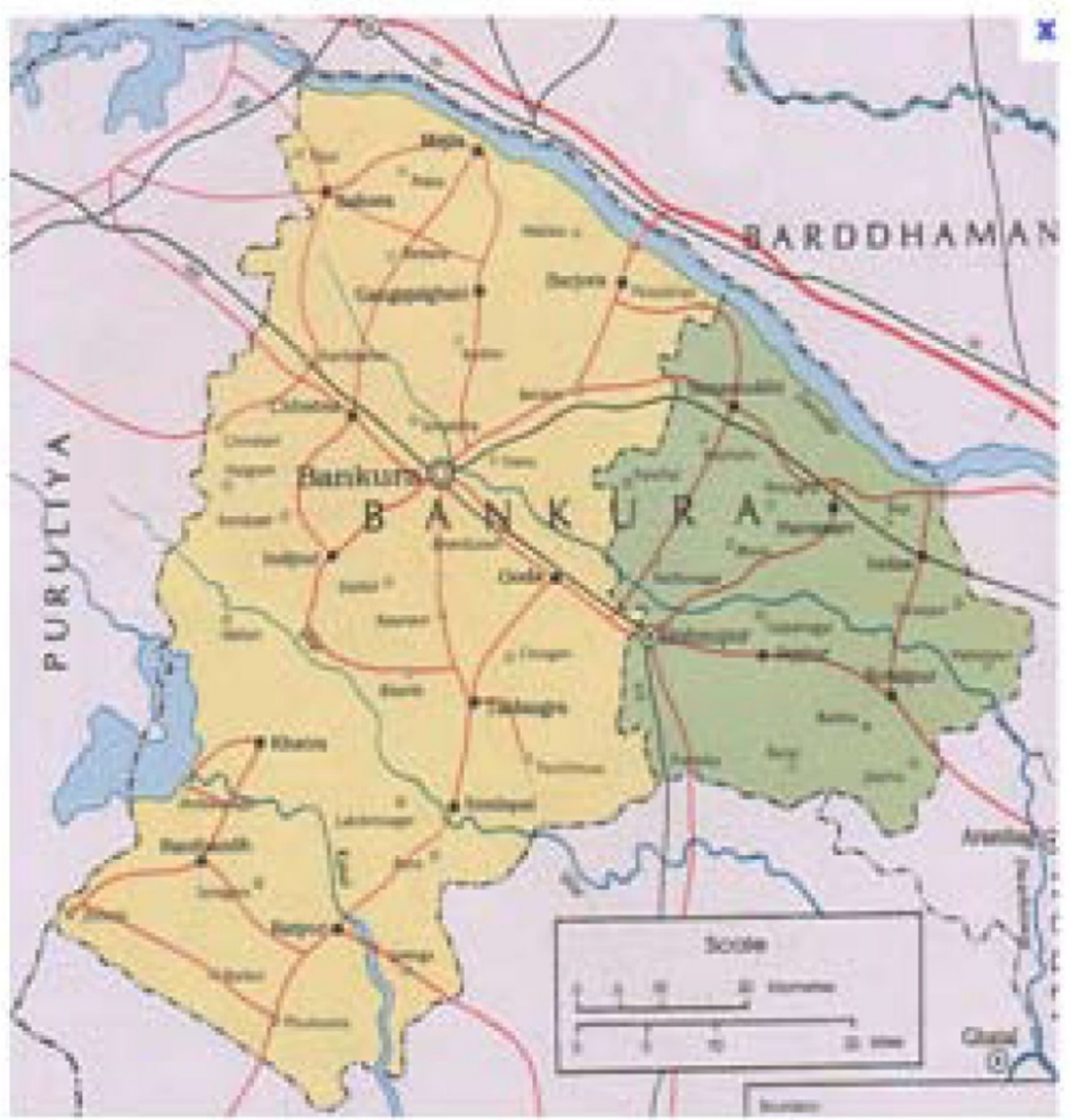

Figure 3 Map showing the drought-prone district of Bankura, West Bengal.

by absentee landowners, or by farmers managing large areas of inferior soil. Farmers in the commercialised growing regions of western and southern India planted woodlots rather than risk-prone crops such as groundnut or cotton. This has been observed on a smaller scale in the deltas of the Mahanadi, Godavari, Krishna and Kaveri Rivers, and in other areas of intensive irrigation development in the lowlands of Gujarat, Maharashtra, and Tamil Nadu. The regions in which farm forestry has been most successful are the semi-arid areas of West Bengal. Districts such as Midnapur, Bankura and Purulia are agriculturally poor, the land holdings are small and most of the production at farm level is used for subsistence. Tree culture succeeded because the Government allotted land unsuitable for agricultural crops to poor agricultural labourers.

Developmental policy such as that underlying the 2005 Mahatma Gandhi National Rural Employment Guarantee Act aims to enhance not only livelihood security of people in rural areas (through guarantee of one hundred days' wage-employment) but addresses some environmental issues. These can contribute to the reduction of greenhouse gas emissions through plantation development and afforestation as well as horticulture, land development, well construction, renovation of ponds and the like. Production of biomass and wood and also carbon sequestration potential were envisaged for activities such as tree planting on crop and tank embankments and wastelands, using a potential conservation growth rate of $3 \mathrm{tha}^{-1} \mathrm{yr}^{-1}$.

\section{Conclusions}

The average carbon sequestration potential associated with agroforestry in India is estimated to be $25 \mathrm{tC} \mathrm{ha}^{-1}$ over 96 million ha. Substantial regional variation is dependent on biomass productivity.

Agroforestry systems offer opportunities for the improvement of the livelihood of poor people through provision of economic and environmental security. Nontimber forest products have been recognised as important resources for both sustainable livelihood and ecosystem conservation purposes.

Agroforestry has a high employment-generation potential in India. Maximum potential has been noted in the cultivation of tree-borne oil seeds, followed by silvipasture systems. 


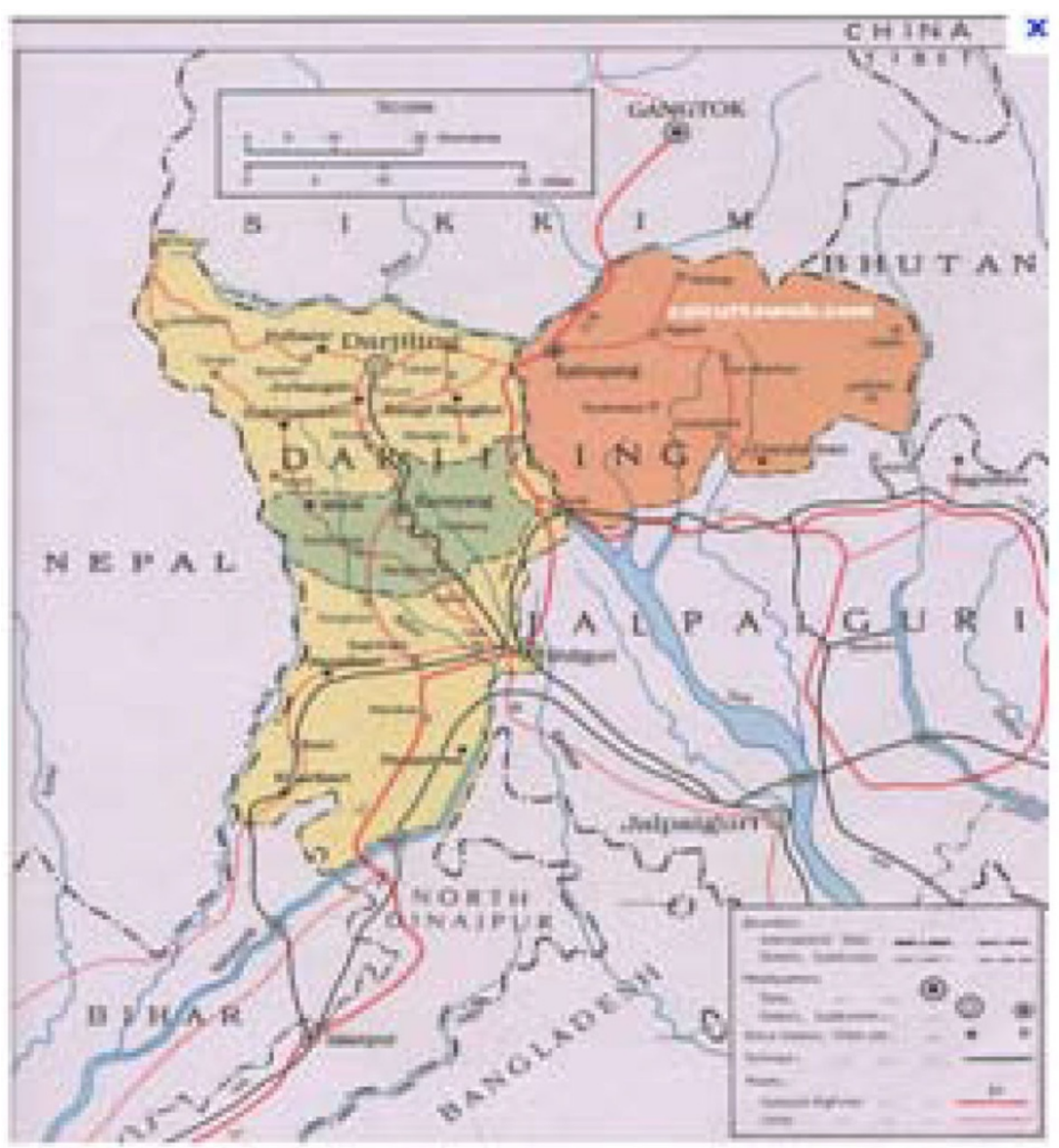

Figure 4 Map showing the mountainous district of Darjeeling, West Bengal.

Successful afforestation, reforestation and smaller tree planting programmes are being implemented by the Indian Government.

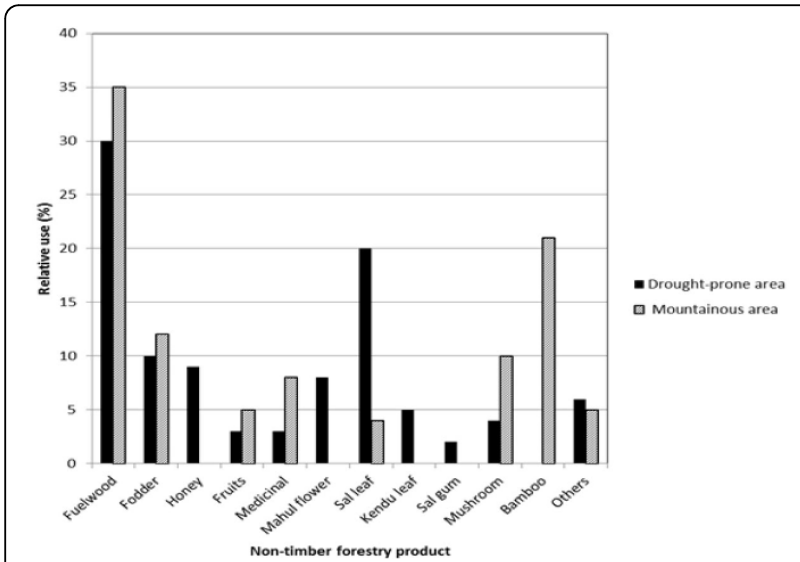

Figure 5 Non-timber forest products used for livelihood in the drought-prone and mountainous areas of West Bengal (Source: Author's calculation).

\section{Endnotes}

1 Carbohydrate can be of different types; monosaccharides (e.g. glucose), disaccharides (e.g. sucrose) and polysaccharides (e.g. starch) and others. Each carbohydrate can be estimated by different quantitative spectrophotometric methods. The carbohydrate content can be expressed in terms of "gramme of carbohydrate/gramme dry weight" of fruits etc, where dry weight $=$ (original weight-water content).

2 The Taungya system is a modified form of shifting cultivation. "Tauang" means hill, "ya" means cultivation, i.e. hill cultivation. It involves cultivation of crops in forests or forest trees in crop fields and was introduced to the Chittagong and Bengal areas of colonial India in 1890. Later it spread throughout Asia, Africa and Latin America. This taungya system is predominant in North-Eastern India.

3 The study was conducted in Pundibari, West Bengal during September 2004 to August 2006, to understand the impact on carbon sequestration potential of different land sue systems like fallow land, agricultural field, pure plantation of Dalbergia sissoo, tea garden, agri-horticulture agroforestry system, pure plantations of Terminalia arjuna 
Table 6 Socio-economic indicators in the West Bengal study area.

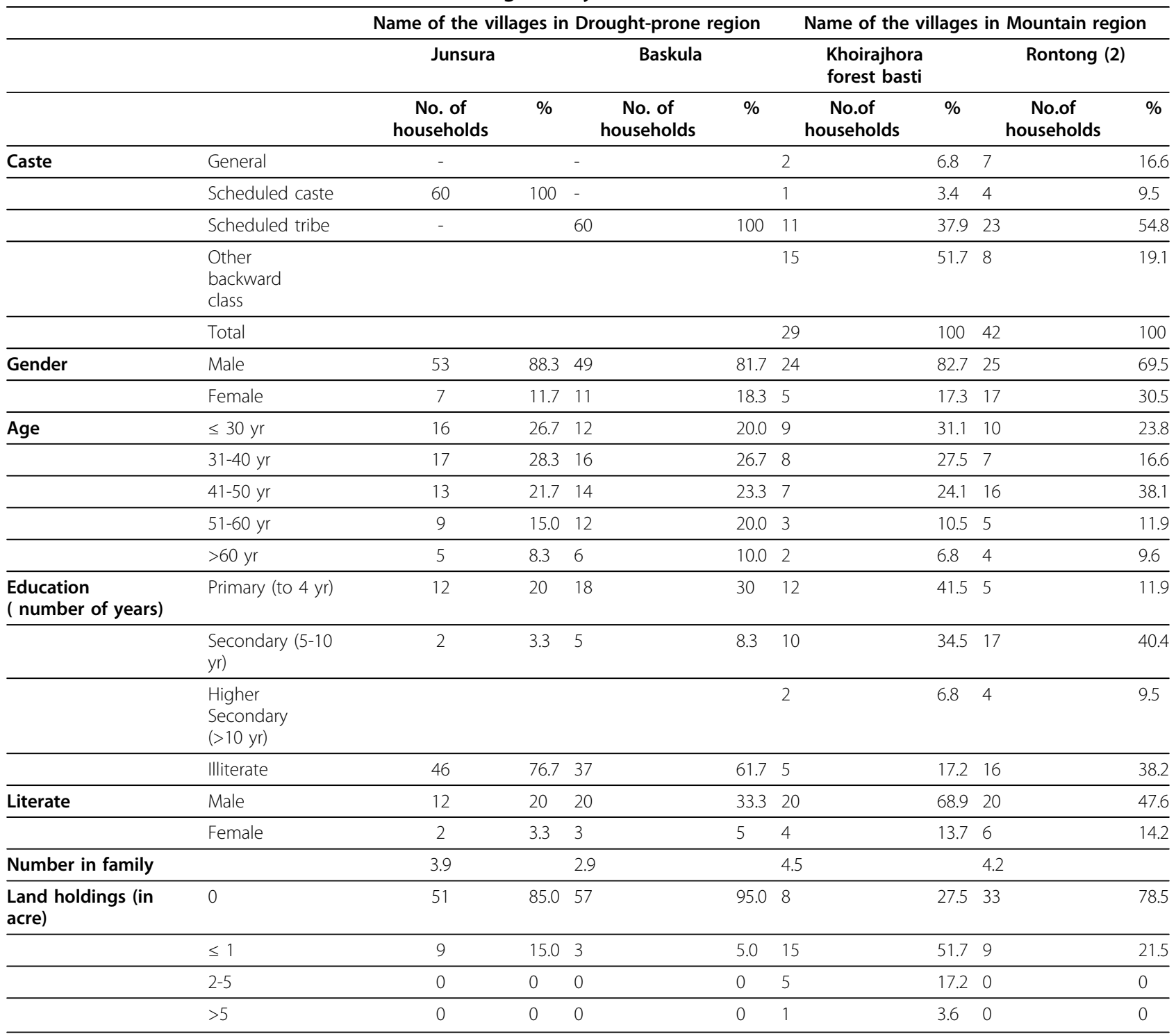

Source: Field survey 2011.

and natural forest of Shorea robusta at four soil depths (09, 10-20, 21-30, 31-40 cm).

\section{Competing interests}

The author declares that he has no competing interests.

\section{Acknowledgements}

I would like to thank the International Union of Forest Research Organisations for supporting me with a full scholarship that allowed me to present this paper in Ireland and Portugal.

\section{Declaration}

Publication of this supplement was funded by the New Zealand Forest Research Institute Limited (trading as Scion).

This article has been published as part of JOURNAL Volume 44 Supplement 1, 2014: Proceedings of the Third International Congress on Planted Forests. The full contents of the supplement are available online at http://www. nzjforestryscience.com/supplements/44/S1.
Published: 26 November 2014

\section{References}

Albrecht A, Kandji ST: Carbon sequestration in tropical agroforestry systems. Agriculture, Ecosystems \& Environment 2003, 99:15-27.

Bhattacharya BP, Misra LK: Production potential and cost-benefit analysis of agrihorticulture agroforestry systems in Northeast India. Journal of Sustainable Agriculture 2003, 22:99-108.

Brown S, Sathaye J, Cannell M, Kauppi P: Management of forests for mitigation of greenhouse gas emissions. In Climate Change 1995: Impacts, Adaptations and Mitigation of Climate Change: Scientific-Technical Analyses. Cambridge, UK and New York, USA: Cambridge University Press;RT Watson, MC Zinyowera, \& RH Moss 1996: Contribution of Working Group II to the Second Assessment Report of the Intergovernmental Panel on Climate Change.

Dhyani SK, Sharda VN, Sharma AR: Agroforestry for water resources conservation: issues, challenges and strategies. In Agroforestry: Potentials and Opportunities. Jodpur, India: Agribios;PS Pathak, \& Ram Newaj 2003:. Dhyani SK, Sharda VN, Sharma AR: Agroforestry for sustainable management of soil, water and environmental quality: Looking back to think ahead. Range Management and Agroforestry 2005, 26(1):71-83. 
Dwivedi MK: Apiculture in Bihar and Jharkhand: A study of costs and margins. Agricultural Marketing 2001, 44(1):12-14.

Forest Survey India (FSI): State of Forest Report 1999. Dehradun, India: Forest Survey of India; 2000.

Forest Survey India (FSI): State of Forest Report 2003. Forest Survey of India, Ministry of Environment and Forests, Dehradun; 2003.

Garg VK: Interaction of tree crops with a sodic soil environment:Potential for rehabilitation of degraded environments. Land Degradation and Development 1998, 9:81-93.

International Panel on Climate Change (IPCC): IPCC Special Report on Land Use, Land Use Change and Forestry. Summary for Policy Makers. Geneva, Switzerland: IPCC; 2000

Jaiswal AK, Sharma KK, Kumar KK, Bhattacharya A: Household's survey for assessing utilisation of conventional lac host trees for lac cultivation. New Agriculturist 2002, 13:13-17.

Jose S: Agroforestry for ecosystem services and environmental benefits: an overview. Agroforestry Systems 2009, 76:1-10.

Koul DN, Shukla G, Panwar P, Chakraborty S: Status of social carbon sequestration under different land use systems in Terai Zone of West Bengal. Environment and We: An International Journal of Science and Technology 2011, 6:95-100.

Kumar R, Gupta PK, Gulati A: Viable agroforestry models and their economics in Yamunanagar District of Haryana and Haridwar District of Uttaranchal. Indian Forester 2004, 130:131-148.

McCarthy JJ, Canziani OF, Leary NA, Dokken DJ, White KS: Climate change 2001: Impacts, adaptation and vulnerability. Cambridge, UK: Cambridge University Press; 2001, 967, (Report of Working Group II;).

Murthy IK, Gupta M, Tomar S, Munsi M, Tiwari R, Hegde GT, Ravindranath NH: Carbon sequestration potential of agroforestry systems in India. Journal of Earth Science \& Climate Change 2013, 4(1):1-7.

National Council of Applied Economic Research (NCAER): Haryana Wood Balance Study (mimeo). New Delhi, India: NCAER; 1987.

National Research Centre for Agroforestry (NRCAF): Vision-2025: NRCAF Perspective Plan Jhansi, India; 2007.

Newaj R, Dhyani SK: Agroforestry for carbon sequestration: Scope and present status. Indian Journal of Agroforestry 2008, 10:1-9.

Oelbermann M, Voroney RP, Gordon AM: Carbon sequestration in tropical and temperate agroforestry systems: a review with examples from Costa Rica and southern Canada. Agriculture Ecosystems and Environment 2004, 104:359-377. Pandey DN: Ethnoforestry: Local knowledge for sustainable forestry and livelihood security. New Delhi, India: Himanshu/AFN; 1998.

Planning Commission, Government of India: Report of the Task Force of Greening India for Livelihood Security and Sustainable Development. 2001. Puri S, Nair PKR: Agroforestry research for development in India: 25 years of experiences of a national program. Agroforestry Systems 2004, 61:437-452. Quli SMS: Agroforestry for NTFPs conservation and economic upliftment of farmers. Indian Forester 2001, 127:1251-1262.

Ramachandran Nair PK, Nair VD, Mohan Kumar B, Showalter JM: Carbon sequestration in agroforestry systems. In Advances in Agronomy. Volume 108. Philadelphia PA, USA: Elsevier;D. Sparks 2010:237-307.

Ravindranath NH: Mitigations and adaptation synergy in forest sector. Mitigation and Adaptation Strategies for Global Change 2007, 12:843-853. Sathaye JA, Ravindranath NH: Climate change mitigation in the energy and forestry sectors of developing countries. Annual Review of Energy \& Environment 1998, 23:387-437.

Saxena NC: Adoption of a long-gestation crop: Eucalyptus growers in N.W. India. Journal of Agricultural Economics 1992, 43(2):257-267.

Singh MP, Dayal N, Singh BS: Importance of genetic conservation of tasar host plants in agroforestry programme in Chhotanagpur region of Bihar. Journal of Palynology 1994, 30:157-163.

Singh VS, Pandey DN: Multifunctional agroforestry systems in India: Sciencebased policy options. RSPCB Occasional Paper No 4 2011, 2-35.

Shit PV, Pati CK: Non-Timber Forest Products for Livelihood Security of Tribal Communities: A Case Study of Paschim Medinipur District, West Bengal. Journal of Human Ecology 2012, 40(2):149-156.

Solomon S, Qin D, Manning M, Chen Z, Marquis M, Averyt KB, Tignor M, Miller HL: Climate Change 2007: The Physical Science Basis. Contribution of Working Group I to the Fourth Assessment Report of the Intergovernmental Panel on Climate Change. Cambridge, UK and New York, NY, USA: Cambridge University Press; 2007, (IPCC Fourth Assessment Report (AR4)).
Sundriyal M, Sundriyal RC: Wild edible plants of the Sikkim Himalaya: Nutritive values of selected species. Economic Botany 2001, 55:377-390.

Torquebiau E: Are tropical agroforestry home gardens sustainable? Agriculture Ecosystem and Environment 1992, 41:189-207.

Trexler MC, Haugen C: Keeping it Green: Tropical Forestry Opportunities for Mitigating Climate Change. Washington DC, USA: World Resources Institute; 1994.

Van Ardenne-van der Hoeven A, Benn H, Malloch Brown M, Chino T, Johnston DJ, Kabbaj O, Nielson P, Töpfer K, Wieczorek-Zeul H, Zhang S: Poverty and climate change: Reducing the vulnerability of the poor through Adaptation. Paris: Organisation for Economic Co-operation and Development; 2003 [http://www.oecd.org/environment/cc/2502872.pdf].

World Bank: Unlocking opportunities for forest-dependent people in India. New Delhi, India: The World Bank Agriculture and Rural Development Sector Unit, South Asia Region; 2006 [http://siteresources.worldbank.org/INDIAEXTN/ Resources/Reports-Publications/366387-1143196617295/

Forestry_Report_volume_l.pdf].

doi:10.1186/1179-5395-44-S1-S11

Cite this article as: Basu: Agroforestry, climate change mitigation and livelihood security in India. New Zealand Journal of Forestry Science 2014 44(Suppl 1):S11.

\section{Submit your manuscript to a SpringerOpen ${ }^{\mathcal{O}}$ journal and benefit from:}

- Convenient online submission

- Rigorous peer review

- Immediate publication on acceptance

- Open access: articles freely available online

- High visibility within the field

- Retaining the copyright to your article

Submit your next manuscript at springeropen.com 